\title{
Archaeology of early medieval peasantry in the Basque Country: Landscapes, economic trends and societal change in Álava
}

JUAN ANTONIO QUIRÓS

KEYWORDS: agrarian economy, village formation, mixed farming, animal husbandry.

JEL CODES: N00, Q00, R14, R20.

7 he aim of this paper is to analyse early medieval economic trends and social change in the Basque Country, using a bottom-up approach that includes multiproxy archaeological evidence. Though comparisons will be made with other Northern Iberian areas, the study focuses on the 3,000 $\mathrm{km}^{2}$ Basque province of Álava, where research has been intense in the last decade. The work primarily relies on records of settlement patterns, paleoenvironmental evidence, field systems, livestock management, food patterns and crop production. Diachronic study of farming and livestock practices show patterns of socio-political interaction between local communities and elite agency in the Early Medieval Age. The main topics analysed are the emergence of local communities, the nucleation process, the use of common resources, the agency of village leaders and the formation of lordships. 


\section{Arqueología del campesinado altomedieval en el País Vasco: Paisajes, tendencias económicas y cambio social en Álava}

\section{PALABRAS CLAVE: economía agraria, formación de aldeas, agri- cultura mixta, cría de animales.}

\section{CÓDIGOS JEL: N00, Q00, R14, R20.}

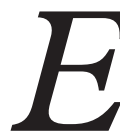

l objetivo de este trabajo es analizar las transformaciones económicas y sociales que tuvieron lugar en el norte de la península Ibérica en la Alta Edad Media a partir del registro arqueológico, recurriendo a un enfoque de "abajo arriba». El estudio se centra en Álava, uno de los territorios históricos del País Vasco de $3000 \mathrm{~km}^{2}$ que ha sido intensivamente indagado en la última década, aunque también se proponen algunas comparaciones con otros sectores norteños. Los principales registros analizados son los patrones de poblamiento, los archivos paleoambientales, los espacios agrarios, las prácticas ganaderas, la alimentación y la producción agraria. El estudio diacrónico de la agricultura y la ganadería permite analizar los espacios de fricción entre las comunidades locales y las élites a lo largo de la Edad Media. Las principales temáticas analizadas son la emergencia de las comunidades locales, el proceso de formación de aldeas, el uso de los comunales, la agencia de las élites locales y la formación de las señorías. paseo de la Universidad, 5, 01006 Vitoria-Gasteiz (Spain).E-mail: quiros.castillo@ehu.eus 


\section{INTRODUCTION}

The link between agrarian history and social change is a key concern of landscapes studies and social science. Given the centrality that rural societies had in pre-industrial times, the analysis of rural landscapes transformation has been considered as a key factor in understanding social complexity in past societies (Johnson \& Earle, 2000), the creation of inequality (Flannery \& Marcus, 2012), the relationship between paleoclimatology, paleoenvironment and human agency (Hassan, 2009), the forms of dominance in the past (Hilton, 1985) or the processes of patrimonialisation of cultural landscapes and traditional societies (Alonso, 2018), among other topics.

Anthropology and archaeology have generated a vast literature focused on the analysis of topics such as water management (Marcus \& Stanish, 2006), the study of intensification/extensification practices (Thurson \& Fisher, 2007), the social dimension of surplus (Morehat \& De Lucia, 2015), storage systems (Manzanilla \& Rothman, 2016), or the productive logics of peasantry (Halstead \& O'Shea, 1989). In addition, the integration of material records, written sources and the ethnographic evidence of agricultural practices has proved particularly effective in addressing the meaning of changes in economic, social and political approaches in some historical turning points, such as the end of the Roman Empire and the beginning of the Medieval period.

The availability in recent years of new material records, resulting from the boom of rural landscapes preventive archaeology in almost all Europe, the construction of more sophisticated records thanks to the implementation of Archaeological Sciences, and a theoretical renewal explain the remarkable development that the study of agricultural history and the study of peasantry in the Late Antique and the Early Medieval Ages is experimenting (i.e. Wickham, 2005; Hamerow, 2012; Loveluck, 2013; Izdebski \& Mulryan, 2019). In fact, in those cases where a significant volume of records has been systematized and centralized, ambitious projects are carried out at a national level where new narratives have been proposed (i.e. McCormick et al., 2014; Hamerow et al., 2019).

Iberia has also undergone a major renovation of studies on rural early medieval societies over the last twenty years. The discovery of numerous peasant settlements, particularly in the north of the peninsula, has allowed key aspects of early medieval society to be re-examined from new perspectives (Escalona, 2009). However, the impact of this renewal is not comparable to that of other European contexts due to a number of factors. The remarkable location of interventions, the attention given to the study of domestic sites over landscapes in its full sense, the scarcity of systematic publications, the absence of projects aimed at creating tools to centralize results of preventive interventions and the still mod- 
est contribution of Archaeological Sciences are some of the main limitations (Martín, 2012; Ariño, 2013; Diarte, 2018; Martínez Jiménez, Sastre \& Tejerizo, 2018; Peña et al. 2019; López Sáez et al., 2019).

As a result, there has been a vivid debate among specialists about the social and political significance of the transformations that took place during this period. After overcoming the simplifying and primitivist approaches, the de-populating and re-populating model, or the teleological narrative of feudalization that have dominated the characterization of rural high-medieval societies in the second half of the twentieth century (e.g. Sánchez Albornoz, 1966; Barbero \& Vigil, 1974; García de Cortázar, 1988), the specialists have been making different interpretative proposals which, in a very schematic way, could be synthesized in three main lines.

A first group of archaeologists and historians have underlined the centrality acquired in this period by peasant societies and the formation of new forms of socialization and organization of rural landscapes. Although the latest works are reclaiming the relevance of peasantry in Roman times (Bermejo, 2017), there is no doubt that the collapse of the Roman Empire created the conditions for a remarkable regionalization of social landscapes within the framework of a deep sub-regional diversity. One of the main contributions of this approach has been to show the agency of peasantry and local authorities, understood as hierarchical and complex subjects, thus overcoming the stereotype of passivity, poverty and simplicity of these subjects. The decentralization of decision-making and the existence of local sociopolitical dynamics are some characteristic features of these societies in Iberia and elsewhere (Vigil-Escalera, 2000; Wickham, 2005: 536-40; Quirós \& Vigil-Escalera, 2006). The main weakness of this approach, built during an early stage of recognition of peasant occupations, has been the fragmentation of the holistic analysis of social landscapes. However, subsequent contributions have made more nuanced proposals including in the analysis elites and non-elites groups agency (Martín, 2012; Vigil-Escalera, 2015; Tejerizo, 2017; Quirós, 2016, 2019).

Although this first proposal has never explicitly defended the fully autonomous nature of these peasant societies ${ }^{1}$, a second group of authors have opposed it with an "aristocratizing model", relying on both textual sources and the accumulation of evidence of the potentes and suggesting patterns of complex hierarchies in rural territory. And while some entity is acknowledged to the profound changes that took place in the articulation of early

1. Following, among others, the R. Hilton statement: in other words the concept of the peasantry as an enclosed community in relation to outside society looks like a euphemism for the relationship between the exploited and the exploiters (HiLTON, 1985: 117). 
medieval landscapes compared to the previous period, it tends to be given priority as a factor of historical change to agents exogenous to local societies: barbarians, the church or distant aristocracies (i. e. Ariño, 2013; Chavarria, 2013, Azkarate \& García Camino, 2012). The main weakness of this approach lies in giving all the prominence of historical change to external actors, without taking into account the internal dynamics of local societies. In addition, the identification of different types of elite and aristocracy representation materiality does not adequately explain how forms of domination, resistance and resilience were articulated, nor the sociopolitical dynamics at a local level.

Finally, another group of authors has maintained substantial social and economic continuity regarding the late imperial period, at least during the first post roman momentum. According to authors such as D. Fernández, not only would there not have been a decentralization of agricultural production, but the "new" peasant economy existed within the context of large properties that still collected rents and taxes, and landowners showed a great capacity of resilience to changing conditions maintaining basic parameters of the economic structure (Fernández, 2017:224). Likewise, studies carried out in monumental sites have emphasized the structural continuity of the forms of dominance in a context of change only of the materiality of residential spaces (e.g. Barroso et al., 2015). The main weakness of this approach is that it fails to satisfactorily explain the transformations of the economic logics and the social practices that are developed at a local level. But they also give excessive priority to the textual documentation generated by the central power in comparison to the diversity that the material record is showing.

The current situation of the research tests the type of inferences that can be made from a partially known material record and which remains mainly focused on inhabited and representation foci. And although numerous steps have been taken in recent years in new directions (Fernández Mier, 2018), in my opinion it is a priority to define at a micro-territorial level a social agricultural history in order to understand patterns and the scale of socio-political systems.

The aim of this paper is to analyse agrarian economy, peasant agency and the articulation of early medieval local societies in northern of Iberia, from the perspective of rural and agrarian archaeology. On this occasion I will mainly concentrate on the territory of Álava, where many different studies have been conducted in the last decade, although I will also make some references to nearby areas, making some comparisons. We already have updated synthesis of Iberia's archaeology in the Early Middle Ages (Diarte, 2018; Martínez Jiménez, Sastre \& Tejerizo, 2018). However, the development of an agricultural archaeology of local societies requires intensive high-resolution multiproxy studies at a micro-territorial level, postponing more significant comparisons for a later moment. 


\section{SETTING THE SCENE: HISTORICAL GEOGRAPHY}

The Basque Country is the easternmost Atlantic territory in the north of the Iberian Peninsula, divided geographically into two main areas: the northern area, with an oceanic climate, home to the provinces of Vizcaya and Guipúzcoa (whose capital cities are Bilbao and San Sebastián); and the southern area, where the province of Álava is located (Fig. 1). Hydrographically, Álava is considered to be in the Mediterranean basin because of its location in the high Ebro valley, but the climate is continental, and is mainly located at considerable altitude. It is barely larger than three thousand square kilometres, but the landscape presents a remarkable variety. In the centre of the province, one of the few northern Iberian plateaus well suited for agriculture (the Álava Plain) is located. Surrounding it, we find mountains in the range of one thousand metres high, where animal husbandry has been traditionally practiced. In the centre of the plain it is situated the early medieval city of Vitoria, the current capital city of the Basque Country. Some distance to the west, the old Roman city of Iruña is located. This city lost its urban status around the fifth century. Although Álava did not have urban centres during the Early Middle Ages, from the ninth and tenth centuries two episcopal centres are known:Valpuesta, to the west, inside the county of Lantarón, and Armentia, in the Álava Plain, inside the county of Álava ${ }^{2}$. To the south and west, rural communities lived on the mountainous areas. The southernmost fringe of the province (the modern Rioja Alavesa) is in the depression formed by the Ebro valley, on the border with the Rioja region. This area is nowadays known for its excellent wines, but during the Early Middle Ages the main production was cereal.

From a socio-political point of view, Chris Wickham defined the Basque Country as one of the Iberian territories with less hierarchy in social and political terms during the Early Middle Ages (Wickham, 2011). Although there are important differences between Álava and the northern provinces, where the material evidence is even more simple, castles were non-existent in Álava until the tenth or eleventh century, and there were never important monasteries such as the ones that existed in La Rioja, Cantabria or Navarre ${ }^{3}$.

During the Early Middle Ages Álava was less political structured than other nearby territories as Pamplona or Oviedo, becoming the periphery of the main political centres of the area. There is no clear evidence suggesting the true integration of Álava in the Gothic or the Merovingian kingdoms after the collapse of the Roman Empire. Later it was always under dispute by Muslins, Asturias, Castile and Navarre, until it was definitely integrated

2. For a framework of the political history see RIVERA (2003).

3. The only exception is the aforementioned monastery-diocese of Valpuesta, located in western Álava. 
in Castile around the year 1200.Throughout this period, the northwest of Iberia was an interesting laboratory for political experimentation. In less than five hundred years, this area gravitated in the orbit of five political entities: the Roman Empire, the Visigothic kingdom, Al-Andalus, the Asturian kingdom and the County of Castile. In this context, political experimentation (collapses, coalescence, creation of new political entities) at different scales was possible, as well as territorial articulation of a variety of agencies that had as main characters not only local elites, but also local communities, which developed sometimes divergent identity and socio-political strategies.

\section{FIGURE 1}

\section{Location of the sites cited in the text}

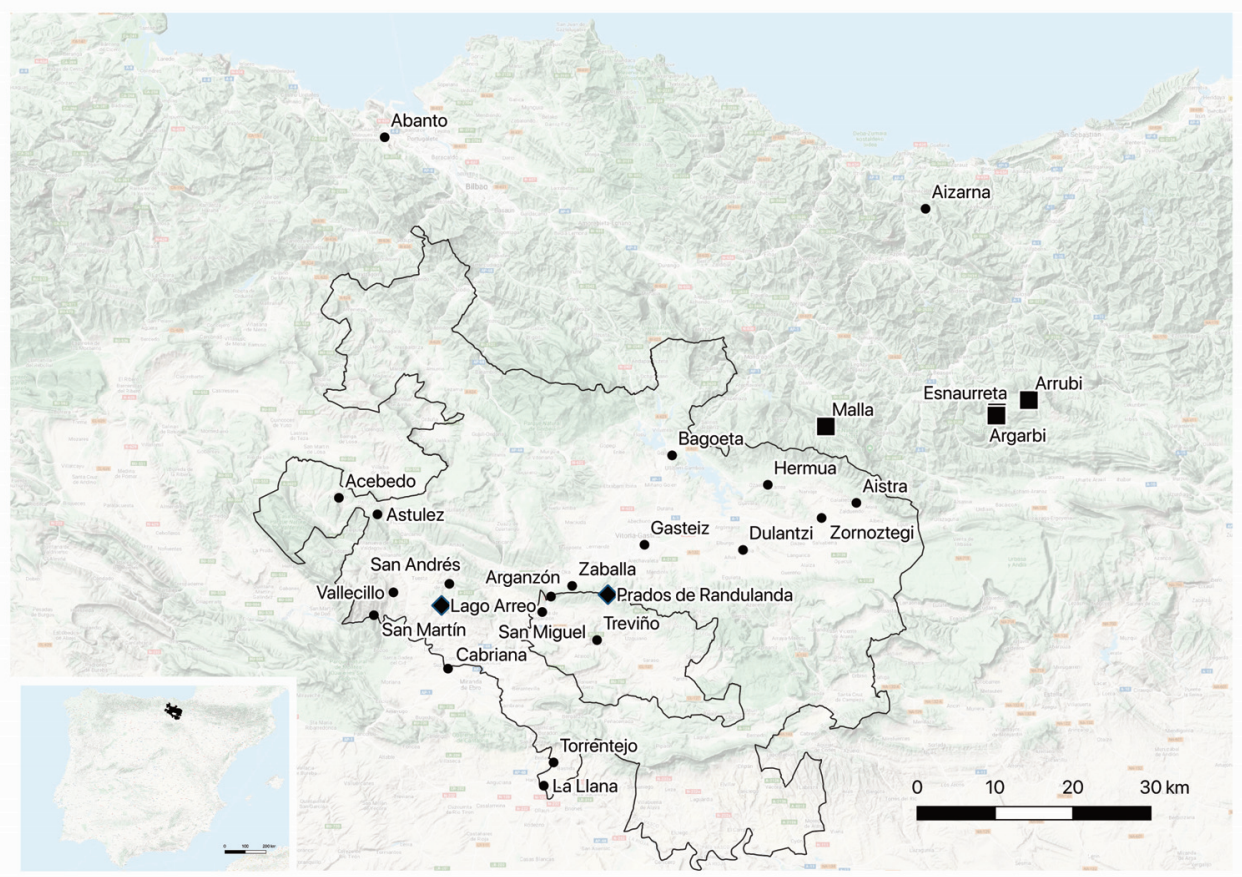

Note: Squares: paleoenvironmental records; Rhombus: mountains sites; Points: valley settlements. Source: Juan Antonio Quirós.

\section{SETTLEMENT PATTERNS AND PALAEO-ENVIRONMENTAL RECORDS}

Evidence of early medieval agrarian practices in Álava are extremely varied. I will first consider landscape and settlement transformations, moving on later to more specific signatures of farming activities. 
Contrary to the paradigm of the scarce romanization of the northern populations, in Roman times Álava was highly integrated into the structures of the empire. Settlement patterns are remarkably hierarchical. The presence of the city of Iruna-Veleia, supposedly abandoned in the late Roman period, several vici and a communication network constitute the main axes of the territorial articulation (Gil \& Filloy, 2000). It is interesting to emphasize that, with the exception of a few sites such as Cabriana or Uralde, the presence of rural villae is virtually unknown. Agricultural landscapes are dominated by small "dispersed" occupations, but dependent in hierarchical terms on central places. In the late roman occupation of Zornoztegi a mixed farming economy pattern is observed, although there are signs of productive specialization (Quirós, 2019). From the fifth and sixth century onwards, new rural settlements were created, although there are also cases of persistence. Instead, the roman central places seem to show a setback.

In order to study settlement pattern, the sum of probabilities of 141 radiocarbon dates obtained from the thirteen medieval deserted villages and one early medieval cemetery ${ }^{4}$ can define the intensity of occupation and the main phases inside each site. In this graph (Fig. 2) we can observe how these settlements started during the fifth century, although occasionally traces of Roman occupation have been identified. This phenomenon, which occurred parallel to the process of abandonment of the rare Roman villa-type estates and their associated structures constituted the moment in which new rural settlements were established. These settlements can be defined as the material expression of permanent local communities that had control over the surrounding territories. It is very difficult to define, in terms of settlement patterns, the rural settlements dated to the sixth and the first decades of the seventh centuries. We only know domestic occupations of this period in a limited number of sites (La Erilla, Vallecillo, Aistra, Zaballa, Zornoztegi, Dulantzi), by contrast to cemeteries (collective burial grounds such as Aldaieta, or smaller ones) or special sites such as the church of Dulantzi, the metal-working site of Bagoeta, or the cave occupations of Las Gobas. In addition, these domestic occupations show a remarkable variety in terms of persistence or architectures. However, there are no traces of a network of villages and farms similar to inner Iberia (Vigil-Escalera, 2007). Summing up, the main pattern emerging from the available evidence dated to 450-650 in Álava is a great heterogeneity. And this conclusion might be extended to other areas of northwestern Iberia.

4. The sites are Zornoztegi (Quirós, 2019), Zaballa (Quirós, 2012b), Aistra (Quirós, 2017), Bagoeta (Azkarate, Martínez Torrecilla \& Solaun, 2011), San Andrés (SÁnChez Rincón, 2011), Santa Coloma (SÁENZ DE URTURI, 2011), San Martín de Lantarón (Quirós, 2012a), La Llana (GiL, 2004), Torrentejo (Quirós \& Nicosia, 2019), Dulantzi (Alfaro et al., 2017), Las Gobas (AzKARATE \& SolAun, 2008), Gaceo (VARÓN, 2013), Arganzón and San Miguel of Arganzón. Regarding the use of radiocarbon dates summation, see STEVENS and FULLER (2012). 
FIGURE 2

Sum of probabilities of 141 radiocarbon dates carried out in some deserted villages and early medieval necropolis excavated in Álava

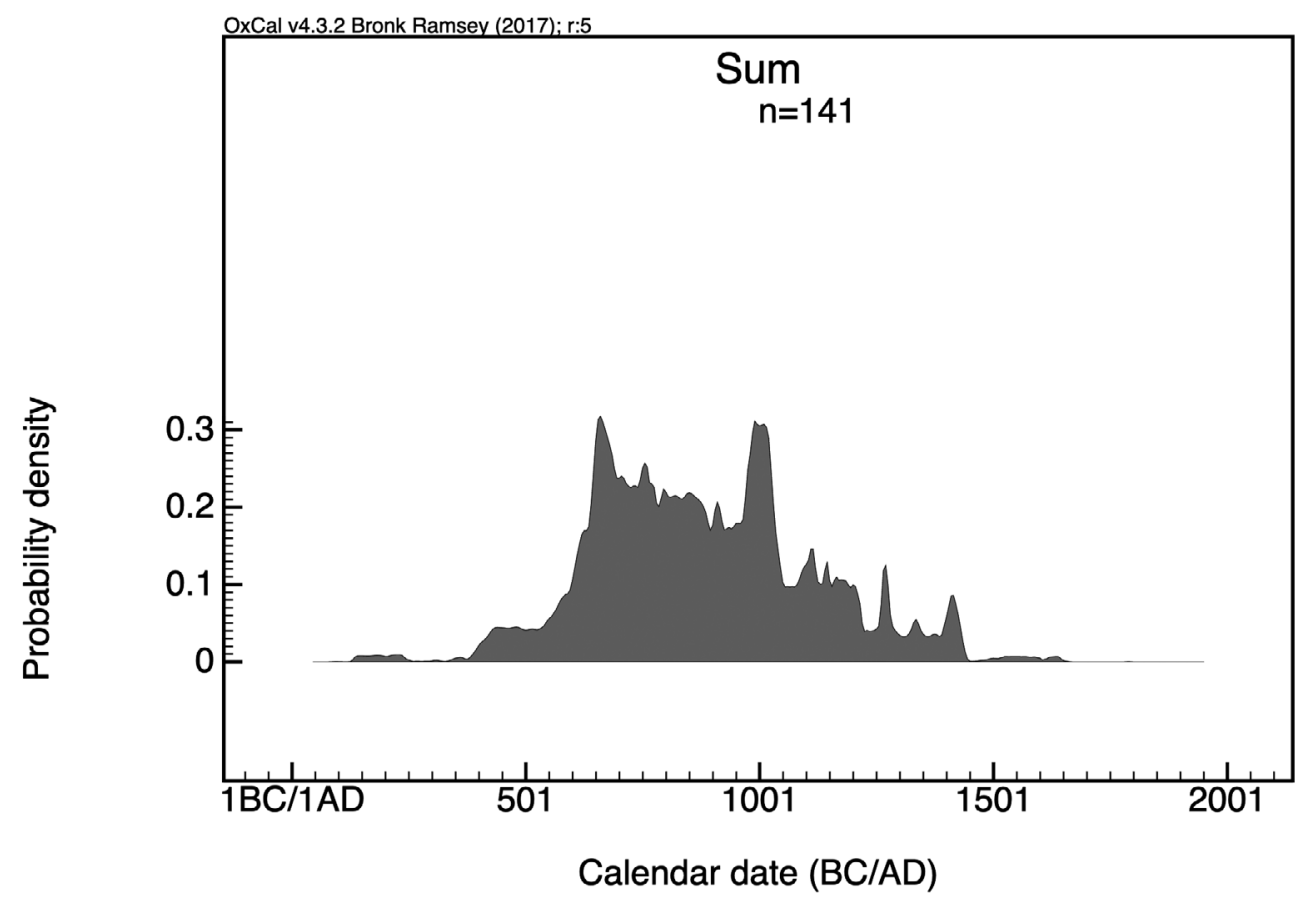

Source: Juan Antonio Quirós.

While palaeoecological records like the ones from the Arreo Lake or the Prados de Randulanda peat bog show signs of intensive land use during the sixth century (Corella et al., 2013; Pérez Díaz \& López Sáez, 2014), bioarchaeological evidence from excavated domestic spaces is too scarce for this period to define farming practices. Similarly, there are few storage structures, although remains of silos have been found in La Erilla, Aistra and Zaballa. Silos are underground structures for long-term storage of strategic supplies meant to face bad harvests. Their diffusion from the fifth century throughout almost all Iberia marks a shift from central management storage systems to small-scale household-based ones, pointing to the decentralization of farming practices into the hands of the local communities (Vigil-Escalera, 2015: 252-55).

Between the late seventh and the eighth centuries we reach the maximum amount of calibration probabilities. This is the period in which a dense village network was created in Álava. In many cases, these villages were located overlying "farmsteads" or previous domestic occupations. Literature carried out during the last decade in Western Europe con- 
firms that the nucleation of rural settlements was a generalised phenomenon that occurred throughout the so-called long eighth century (Hamerow, 2002: 121-24; Crabtree, 2010; Rippon, 2010). However, until this time scholars have only been able to provide regional explanations for this phenomenon that seems to be fairly global (Astill, 2010).

This process occurred in Álava at different stages in different areas: it seems that those villages located close to the Ebro river (San Martín de Lantarón and Torrentejo, dated in the seventh century; the oldest dates of La Llana can be dated to about the eighth to ninth centuries) were created earlier than those at the Álava Plain or on the western mountains ${ }^{5}$. A possible explanation for this asymmetry can be found in the different degrees of political maturity seen in the EbroValley, where there are aristocratic centres like the residence of the senator Honorio, located in Parpalinas (La Rioja) and various castles occupied already from the fifth to the seventh centuries, as opposed to the nuclear area of Álava, lacking analogous entities ${ }^{6}$. However, even in compact territories such as the Álava Plain a number of differences have been noted (Quirós, 2020a).

Palaeoenvironmental records also show this pressure over the landscape or, at least, over the mountains and forested areas. Arboreal pollen shows during this period a remarkable decrease (from the $26-38 \%$ between the fourth and the sixth centuries, to $11 \%$ ), as the result of a process of crop-extension (Hernández Beloqui, 2015).

Changes in palaeoenvironmental conditions can be related to transformations of the management agrarian resources and farming practices. At every early medieval village, a great number of silos or storage pits, similar to those of the previous period, have been identified. Their estimated capacity is around 1,200-2,000 litres. These structures are located within the households and were therefore used at a family level. The silos are absent, interestingly, at the centre state of Aistra or Dulantzi in the eighth and ninth centuries (Quirós, 2017; Alfaro et al., 2017) ${ }^{7}$. It seems plausible that crops were stored in raised granaries built on posts or other type of storage system larger than the "family-silos". This absence is highly significant, because it could indicate that cereals were regularly supplied to Aistra as rents or that, at least, it was not necessary to face possible risks as a result of bad harvests. On the other hand, the number of hunted animals, the consumption of young animals, and the high proportion of pork appear to be markers of an

5. This is the case of San Martín de Lantarón (Quirós, 2012a) or Torrentejo (QuiRós \& Nicosia, 2019; NARBARTE-FERNÁNDEZ et al., 2020).

6. About Parpalinas, see EsPINOSA (2011); about castles in the Ebro Valley, see TEJADO (2012). One of the most relevant is Castro Bilibio, mentioned in the seventh century (OROZ, 1978: 189).

7. Regarding the problems of the identification of estate centres, see LOVELUCK (2013: 73-5). 
elite lifestyle (Grau, 2015a). In this sense, it is important to mention that the consumption of relevant quantities of pork, and meat in general, has been interpreted as a marker of high social status in Britain, France and Iberia (Grant, 2002; Durand \& Leveau, 2004; Loveluck, 2013; Grau, 2017).

The analysis of consumption patterns allows us to characterise more clearly these rural communities. For example, the absence of pork limbs and the particularly high percentage of cattle killed during the autumn in Zornoztegi suggest that part of the inhabitants had a highly dependent status and had to pay rents. Tellingly, such evidence is absent from Zaballa or Gasteiz. And despite archaeology's limitations to define the legal or social status of the medieval peasantry, this is an extremely heterogeneous reality, both within and between the settlements, given the diversity of consumption patterns and domestic records. The presence of synchronic silos within some villages can be used as a sign of the existence of enriched peasants and the emergence of local elites based on economic resources. Conversely, long-lasting buildings have had a key role in the foundation of stable communities and the creation of competitive social memories (Quirós, 2019, 2020a).

Around $\mathrm{AD} 1000$, the sum of calibration probabilities reaches another peak. The institutionalisation of inequalities during the tenth century resulted in the conformation and reconfiguration of political realities that provide the basis of early medieval monarchies and their territorialities. It is at this moment that the dioceses of Valpuesta (in the west of Álava) and Armentia (on the plateau) were created, in the process of conformation of Castilian counties.

Palaeoenvironmental records show clear changes in territorial management during this period. At the Lake of Arreo the most intense land use of the last two millennia was identified for the period between the tenth and the twelfth centuries (Corella et al., 2013: 565). Archaeological research on rural settlement points towards the same idea: this is the moment when a true process of agrarian intensification is transformed into the building of traditional agrarian terraces.

The settlement record shows some changes. Firstly, we see the establishment of fortified settlements at the initiative of lords, following a pattern of incastellamento, though there are some important differences with the classic Mediterranean model proposed by P. Toubert. This is the case of Treviño, Arganzón and probably Labastida, where concentration processes of peasant populations by lordship initiative has been inferred. Such processes are attested in a few areas in the south of Álava. 
Besides this, new villages are created, and some changes are attested in the older sites. In this period, a second phase of private churches and monasteries inside the villages foundations is attested. Some villages started to differentiate themselves in economic and socio-political terms; such is the case of Gasteiz, where there is evidence for the existence of metallurgic centres placed inside trading networks (Azkarate \& Solaun, 2013). Aistra's decline from this period may suggest that some of the most active early medieval territorial authorities were supplanted by these new emerging realities. Also, some local leaders within villages such as Zornoztegi decline (Quirós, 2017, 2019).

\section{FIGURE 3}

\section{The palatium of Torrentejo (Labastida, Álava)}

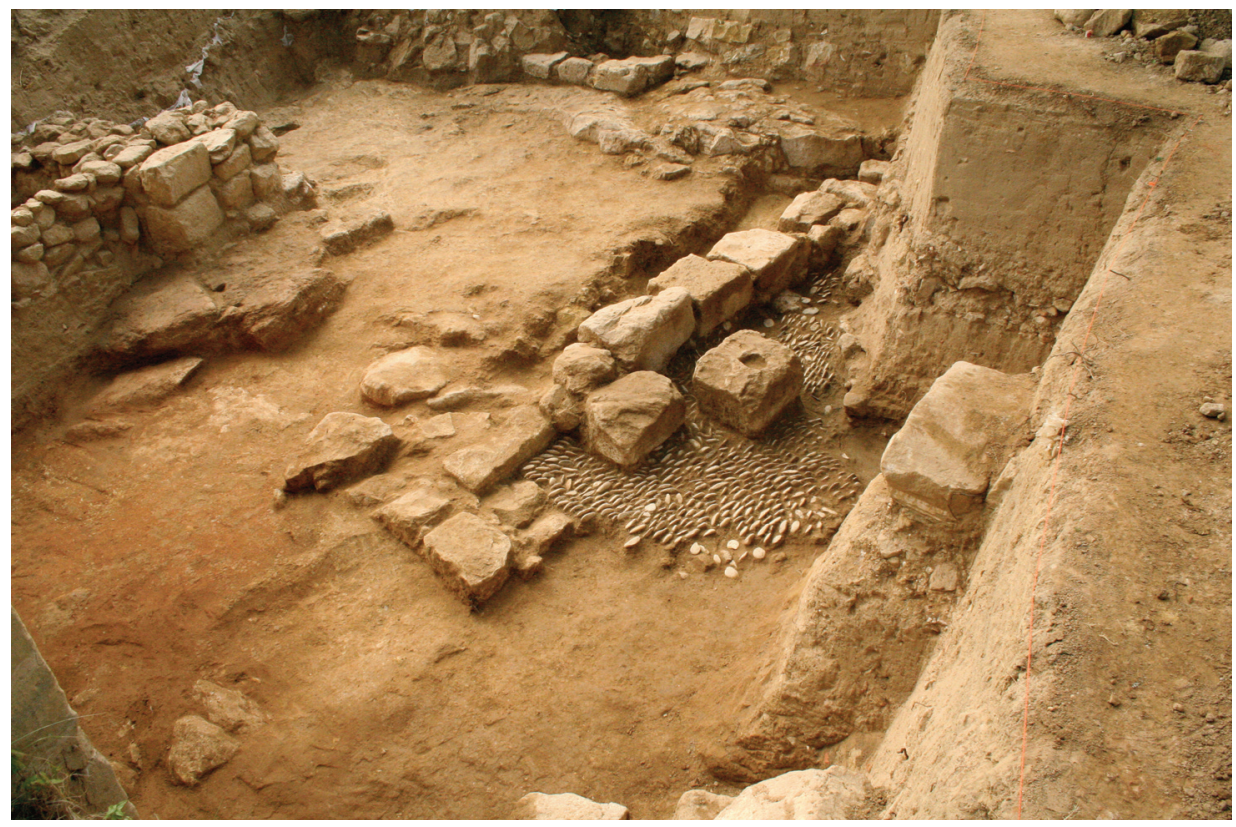

Source: Juan Antonio Quirós.

The progressive consolidation of lordships caused a remarkable increase of systems for the payment of rents. In fact, the definition and the material identification of the powerful is now achieved by means of different consumption patterns, but also through the existence of places specially designed for accumulating rents. At the castle of Treviño, the church of Dulantzi or at the monastery of Zaballa, we have found groups of huge silos (at least 3,000-5,000 litres) that were certainly used to store crops for speculation. As opposed to the peasant silos whose aim is to guarantee the survival of the family in the event of possible risks, seigniorial silos acted as centralised reserves that, in emergency situations, were used to supply cereals to peasants under the lord's control -or soon-to-be-, thus in- 
creasing his dominion and wealth. Additionally, the palatia mentioned in the texts might have had to build centres to gather rents (Escalona \& Martín, 2013), such as the Torrentejo example (Fig. 3). From this moment, a significant change in the nature and mechanisms of the exercise of power occurred. Moreover, at the castle of Treviño, evidence has been found suggesting the existence of consumption patterns of high-status social groups: meaningful consumption of meat in general and of young animals in particular. During this period, the capability to interfere in and control agrarian practices is remarkable.

On the other hand, in all villages in Álava peasant or "family silos" for storing strategic stock still existed, which suggests that, rather than the substitution of a decentralized system with a centralizing one based on speculation, very different realities co-existed under strong tensions. Unlike horrea, peasant silos are totally absent in written documents and, being underground, they were very likely hidden, as ethnoarchaeological evidence has suggested. Ultimately, the process of lordship imposition during the tenth to twelfth centuries in Álava does not exclude peasant agency in terms of seed sovereignty and risk management. After the twelfth century, storing silos also disappeared from most of the villages, which was the result of the use of open-air barns, as well as of new trading systems for supplying staples, which had the emerging proto-urban centres, funded by royal powers.

Summing up, settlement patterns and the use of land show the existence of a hierarchical social landscape from the beginning of the Early Middle Ages even though the scale of the political system is limited in terms of connections, ambitions and agency if compared to other Iberian contexts. Commons resources and the construction of social memory are key to understand grouping in this period, despite the effect of nucleation and village formation. Finally, it should be pointed out that Álava shows signs of relevant subregional differences.

\section{THE ARCHAEOLOGY OF FIELD SYSTEMS}

The study of local societies requires not only the analysis of residential sites, but also the sites of farming production.

During the last fifteen years a number of studies of traditional field systems have been carried out in Galicia, Asturias and the Basque Country, thanks to the development of protocols for geo- and bioarchaeological analysis (Fernández Mier, 2018). Although we must avoid thinking that traditional agrarian landscapes are fossils that have not changed, it is also apparent that the oldest phases of surviving agrarian units can be dated to the Early Middle Ages. The regional diversity is notable: in Galicia, the formation process of 
these field systems developed mainly after the sixth and seventh centuries, but in Asturias, it seems that this process only occurred after the eighth century ${ }^{8}$.

The medieval agrarian systems analysed in the Basque Country show a chronological polarization in two main phases: the sixth to seventh centuries, and the tenth to twelfth centuries (Fig. 4). While the first phase can be related to new grouping initiatives, even if settlement were based on scatter patterns, and the creation of agrarian landscapes (Quirós, 2020a), the second phase marks the period of maximum agrarian intensification. And, although frequently these processes of cultivation and construction of agricultural terraces were a response to small-scale initiatives, we can try to relate these tendencies to broader processes.

FIGURE 4

Chronology of agrarian spaces excavated in some of the major archaeological projects of the Basque Country

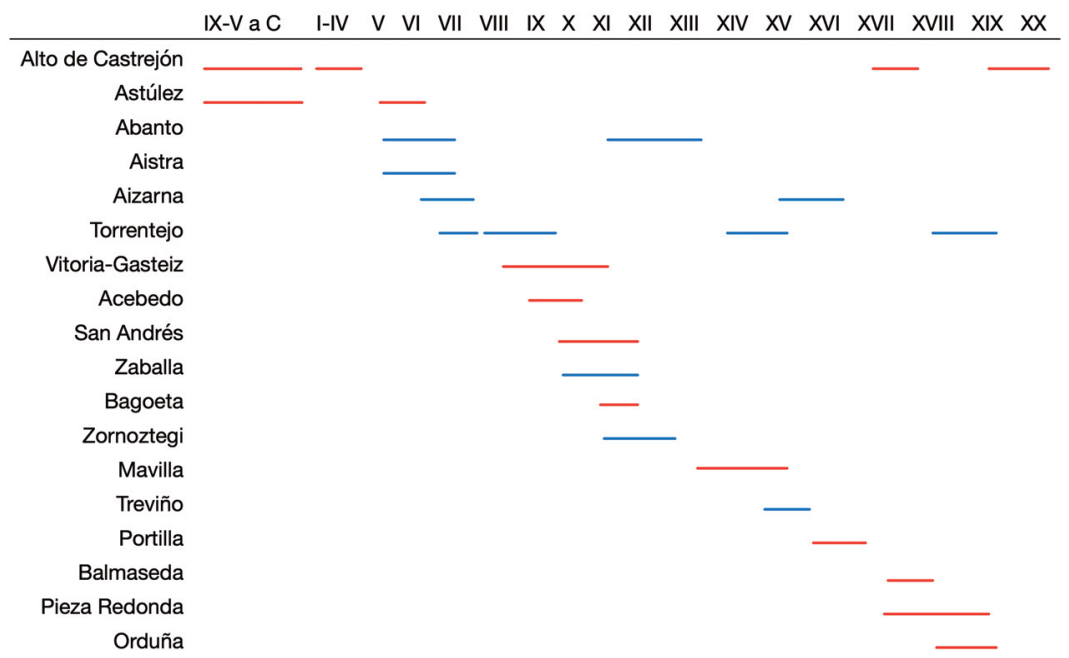

Note: fine lines indicate projects focused on agrarian archaeology; thick red lines characterize projects focused mainly on settlements; segments are related to the chronologies of the agrarian structures. Source: Juan Antonio Quirós.

It is quite remarkable that we have not found any cultivation space that could be dated to the eighth century, which is when a stable village network seems to have been created. The only exception is constituted by the system of agrarian terraces of Torrentejo, built

8. For Galicia, see Ballesteros, Criado and ANdrade (2006); for Asturias, see Fernández Mier et al. (2014); for the Basque Country, see QuiRós (2014). 
during the sixth-seventh century and renovated at the end of the eighth or ninth centuries (Quirós \& Nicosia, 2019).

The construction of these field systems is a direct testimony of the collective action of peasant co-resident or non-co-resident. On the other hand, the entity of these works shows not only the coordinated action of the whole community, but also the existence of some sort of internal or external ways of coordination or direction. And, although the oldest agrarian systems are smaller, their construction after the tenth century confirms the process of agrarian intensification and the investment in landscape capital.

For example, in Zaballa, the first attested phase of human impact consisted of the clearing of vegetation by burning the slopes. The next step was the import of large volumes of soil material mixed with domestic waste. It has been estimated that more than $1,000 \mathrm{~m}^{3}$ of soil were transported, which caused major transformation in both the landscape and the urbanism of the village. Furthermore, the construction of cultivation fields in Zornoztegi during the eleventh to twelfth centuries is related to the reorganization of the space of the village surrounding the church of Santa María, through the re-deposition of almost $2,000 \mathrm{~m}^{3}$ of soil at once. While in the case of Zaballa we can interpret the reorganization of the agrarian space inside as the process of creation of a lordship monastery around $\mathrm{AD} 950$, in the case of Zornoztegi such transformations are related to the establishment of the parish of Santa María (Quirós, 2019). It seems clear that from the tenth to the twelfth centuries local powers are more efficient in demanding and obtaining rents, However, the diversity of chronologies and the processes of transformation of terraces in the analysed villages suggest that the ways of responding to seigniorial pressure were very different, even contradictory, as a reflection of the autonomy granted to peasant communities. Meanwhile, in Torrentejo, an example of a village under tight and hegemonic lordship control at least from the eleventh century, no evidence suggests an intensification of the production, manure practices or a modification of agrarian terraces. Also, it is interesting to notice the close relationship in Zaballa between the foundation of the monastery and the modification of agrarian spaces in the tenth century, or the nature and chronologies of the interventions carried out in Zornoztegi. To sum up, peasant agency follows processes that are not directly related to those of local powers.

Chemical markers and soil micromorphology show that these agrarian fields had a multifunctional use, making it complicated to define the social practices carried out on them. Nevertheless, available documentary evidence mentions, from the ninth century, the existence of spaces of openfield type that were semi-collectively managed (Alfonso de Saldaña, 1974). We could therefore suggest that, in the Basque Country, some collective initiatives have been conducted in order to improve agrarian practices. 


\section{FIGURE 5}

Flint sickle dated to the fifth century from Zornoztegi (Salvatierra, Álava)

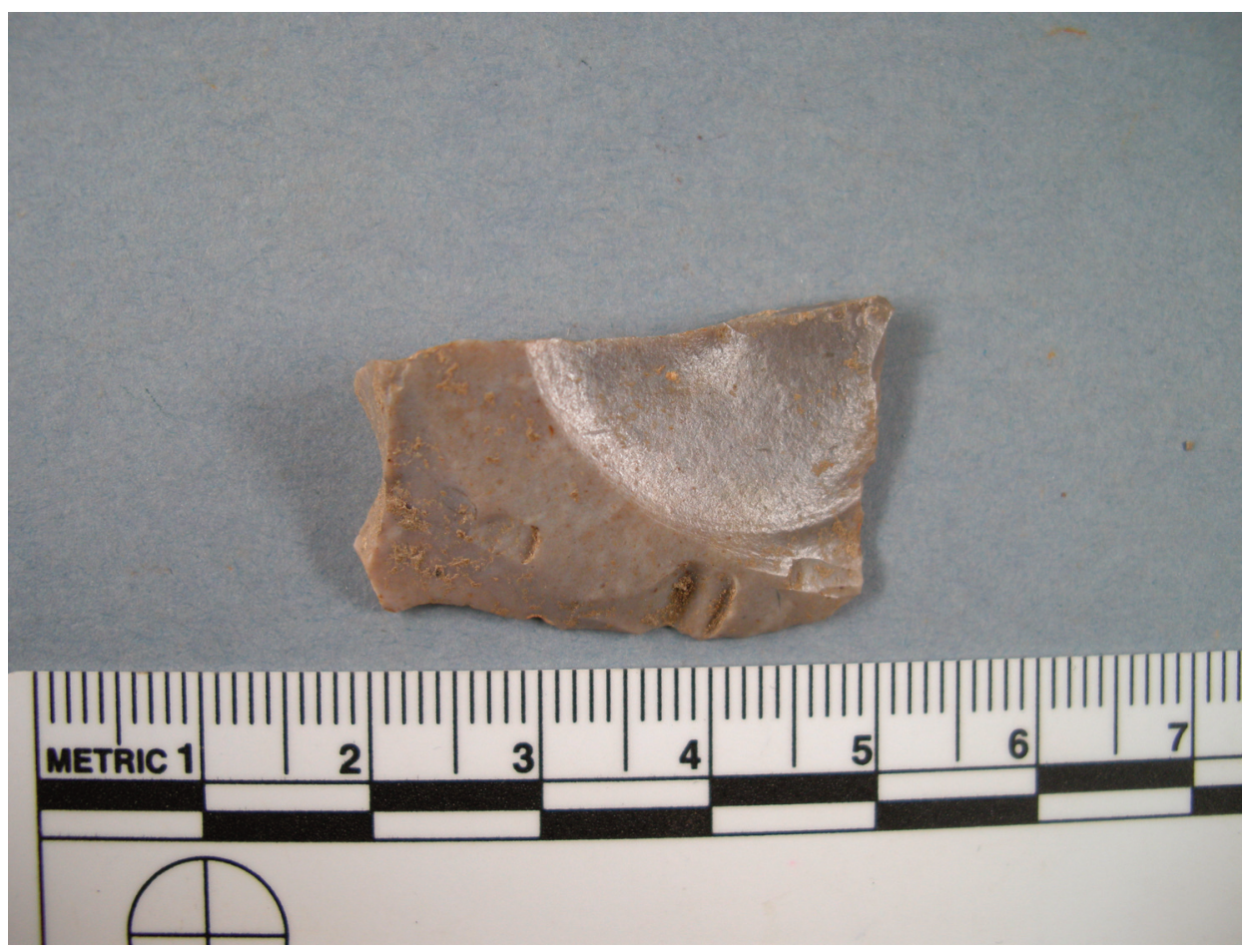

Source: Juan Antonio Quirós.

The information available regarding the agrarian techniques, practices and strategies is still very partial. However, some tendencies already emerge. On the one hand, we know that early medieval peasants employed a relevant number of iron tools for agricultural activities. In the last few years, more than three hundred haizeolak or shaft furnaces have been identified, mainly inside communal spaces of Bizkaia and Gipuzkoa. The available chronologies suggest that these structures were under continuous use between the Roman period and the thirteenth century, when hydraulic technology was introduced. This is small-scale production based on the exploitation of communal resources, even though more sophisticated patterns of production have been recorded in other areas (Franco, Etxezarraga \& Alberdi, 2015).

Although such metallic tools were regularly recycled, in some sites, such as Zornoztegi or Zaballa, a number of iron tools have been recovered. The case of Zornoztegi is especially significant: the only sickle found in the late Roman period was made with flint stone, a material that was used, throughout the entire historic period, to fabricate threshing 
boards, spark lighters and sickles. At the early medieval village, however, iron sickles and other iron agricultural tools are common (Fig. 5).

On the other hand, the productive strategy exhibited in most of the sites we have analysed is characterised by non-specialized agrarian practices, based on the diversification of production, in order to minimise possible risks. This mixed agriculture, very closely integrated with stable animal husbandry which, among other things, would provide manure and traction power, was based on the cultivation of cereals and pulses. According to the written documents, between the ninth and twelfth centuries, peasants were required to pay rents in wheat and barley, but peasant economy followed other parameters.

In Zaballa, for example, barley and wheat make up less than one third of the carpological remains found in early medieval contexts. Pulses and fruits were, however, very important in the peasant diet. Apart from these long-cycle bread grains, other cereals had great significance, despite frequently being considered minor, as they were not used for paying lordly rents. This is the case with millet. The cultivation was part of the peasants' strategy for productive diversification, as it yields two harvests per year. Millet was important in Álava throughout the Early Middle Ages, at least from the seventh century, used both for human and animal consumption. The co-existence of both types of cereals (fodder and pulses) in consumption contexts and the close integration with animal husbandry suggests that, at least from the eighth century, crop rotation might have been part of the agrarian practices of peasant communities in Álava (Sopelana, 2012; Pérez Díaz et al., 2015).

The consumption of $\mathrm{C} 4$ cereals is evidenced as well by the isotopic analyses of human remains. In the early medieval cemeteries of Dulantzi or Aistra the buried seem to have had access to a wide range of food, as a reflection of productive diversification and social differences. Some individuals, however, consumed C4 cereals prevalently. A completely opposite situation has been observed in the high medieval contexts of the Treviño castle, where we identified an enrichment over the herbivore baseline that can be interpreted as greater consumption of animal proteins. From this moment onwards, the peasant diet in Zaballa or Zornoztegi also became more monotonous and vegetarian (Lubritto et al., 2017). In fact, from the High Middle Ages, more specialized strategies for cereal production have been attested. For example, in eleventh century Gasteiz the consumption of wheat increased, while in Zaballa it was not until the thirteenth century that a polarization of the cultivation of barley occurred (Sopelana, 2012; Pérez Díaz et al., 2015).

Finally, surveys and the archaeological study of field systems have shown that it is not possible to detect the use of domestic residues for manuring fields during the Early Medieval Ages. 
Summing up, the Álava record shows the role of mixed farming during the late antique and the early medieval period based on extensification (large-scale, low-input) rather than intensification (small-scale, high-input), crop diversification and multifunctionality instead of specialization and a remarkable economic fragmentation, coinciding with other material markers, such as pottery production and distribution (Solaun, 2005).

\section{EARLY MEDIEVAL ANIMAL HUSBANDRY}

The archaeological study of animal husbandry practices cannot be separated from the analysis of agricultural practices during this period. And although several works carried out in recent years have highlighted the existence of forms of husbandry specialization in different sectors of early medieval Iberia (e.g. Chavarria, Lewit \& Izdebski, 2019; López Sáez et al., 2019), the Álava record should be interpreted in terms of extensive husbandry related to the expansion of small-scale mixed farming practices. In places such as the Álava Plain orValdegobia it may be suggested that a vertical transhumance (between mountains and plains) would have been developed by connecting the valley occupations and the mountain spaces, where pastures and other spaces of seasonal use would be located within the framework of a strategy based on the diversification of resources. What is more, the shared use of these resources would have generated the creation of collective identities and negotiation and distension practices that are at the basis of common resources pools (Fernández Mier \& Quirós, 2015). There are several records that allow us to characterize animal husbandry in early medieval Álava.

Archaeological interventions have been carried out on some pens and huts located on high altitude mountains, such as the meadows of Urbia and Malla in Aitzkorri and in Aralar, which were used seasonally during the summer for animal grazing ${ }^{9}$. The graph showing the sum of probabilities of several of these excavations (Fig. 6) and the palaeoecological evidence suggests some ideas:

a) Pollen evidence suggests that human pressure over mountain spaces in Álava and its surroundings was not particularly intense during the Roman period; therefore, it has been suggested that the practice of animal husbandry did not substantially change a landscape mainly covered by trees. The activity on the Pyrenees or on the Cantabrian Mountains during this period was not very significant either (Galop et al., 2013). Moreover, mountain huts dated to this period are

9. Regarding Urbia, see Llanos and Urteaga (2002); for Malla, see Stagno and Tejerizo (2016); about Aralar, see MorAZA and MujIKA (2005), and MujIKA et al. (2013). 
extremely rare. Recently, two late Roman-period mountain huts have been identified in Argarbi (Gipuzkoa), at more than 800 metres a. s. 1. They have been interpreted as shepherds' seasonal shelters (Mujika et al., 2013). One explanation for the scarcity of evidence for livestock breeding in mountain areas in the Roman period is that a more complex long-distance transhumance system existed, integrating different ecological areas.

FIGURE 6

Sum of probabilities of $\mathbf{3 3}$ radiocarbon dates carried out in the pastoral occupations at the mountains of Aitzkorri and Aralar

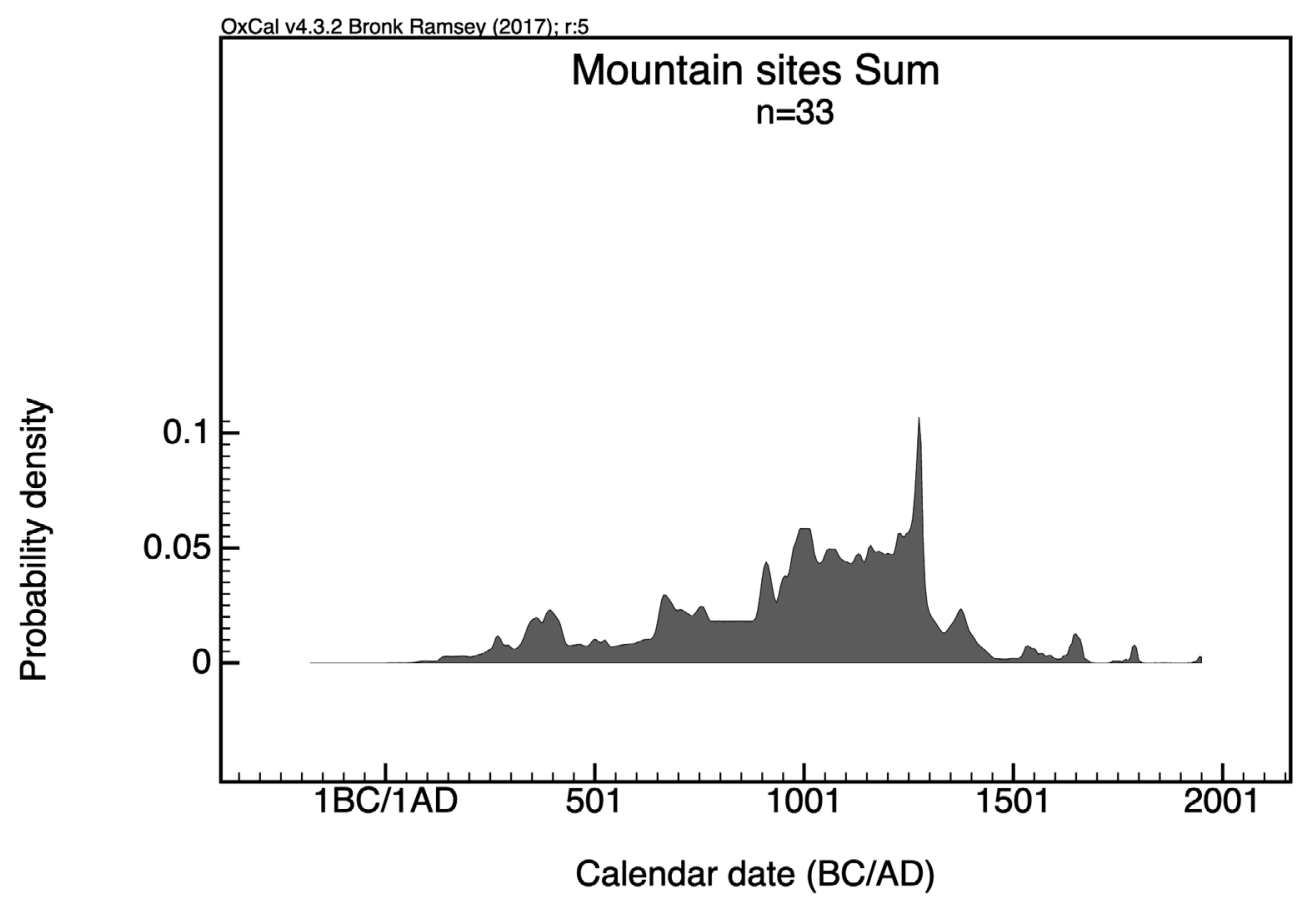

Source: Juan Antonio Quirós.

b) According to the graph, during the Early Middle Ages, on the contrary, a systematic appropriation of mountain spaces by the local communities occurred. These new sociability frameworks determined the formation, re-elaboration and consolidation of communal practices, both in the valley and on the mountains. The pollen records from Prados de Randulanda are clear, showing not only deforestation processes at high altitudes, but also the presence of cereal cultivation spaces, perhaps associated with occasional use of peripheral areas or with seasonal cultivations by the summer herders using the mountain huts (Pérez 
Díaz \& López Sáez, 2014). Through the sum of probabilities, we can infer that such occupations increased progressively throughout the Early and High Middle Ages, reaching their peak during the fourteenth century. Other two peaks can be observed, in the eighth and tenth centuries, as a reflection of the valley transformations mentioned earlier. The mountain huts of Arrubi and Esnaurreta, dated respectively between the eighth and tenth centuries and the seventh and ninth centuries, are the best-known examples (Agirre et al., 2008). This development of vertical transhumance animal husbandry practices by peasant communities is the result of social and economic conditions caused by the consolidation of village networks and the reorganization of communal spaces.

c) Finally, in the archaeological record it is not possible yet to detect lordship herds. This silence is particularly striking considering that they are very visible in written documents between the ninth and tenth centuries. The co-existence of systems of vertical transhumance practiced both by peasant communities and manorial herds and long-radius transhumant flocks must have caused serious issues regarding the management of summer grazing areas on the mountains (Barceló, 1995).

Besides, recent isotopic studies carried out on faunal remains have led to the identification of changes in the way early medieval livestock was fed in Álava, which basically reflects changes in livestock management practices. Pigs make the most significant case. The isotopic values of early medieval pigs from Álava are very similar to those of herbivore animals, suggesting that they were kept free range in wooded pastures, mainly fed on acorn and other vegetables. High medieval pigs, on the contrary, have very similar isotopic values to those of humans, suggesting that their diet was mainly omnivorous, and were probably fed from domestic food scraps. This change, which happened at approximately $\mathrm{AD} 1000$, may be considered an important marker of the transformations that occurred during the High Middle Ages, when the pressure over woodland increased and access to communal areas was restricted as a result of increasing cultivation (Sirignano $e t$ al., 2014). And, although we know little about the methods of regulating and controlling forest spaces during this period, we must think that from the year 1000 such spaces are subdued in Álava to new communal management ways, making some past practices obsolete $^{10}$.

10. Only from the Late Middle Ages do we see significant written documents about the management of forest resources showing the degree of existing conflict between these spaces (DíAZ DE DURANA, 1986: 320-22). 
Finally, the most important contribution to our understanding of medieval animal husbandry in Álava comes from the analysis of faunal remains recovered in deserted villages (Grau, 2015a). One of the most interesting conclusions of this study is that between the eighth and the tenth centuries, the relative proportions of cattle increased in Álava (Aistra or Zornoztegi), in comparison with the earlier phases when sheep/goats dominated (Dulantzi or Aistra) ${ }^{11}$. According to the kill-off patterns, cattle were mainly used for traction in agriculture. Both patterns may suggest a process of agricultural intensification in same cases related to the consolidation of the village network. In other occasions, such as Zaballa or Gasteiz, this pattern is not attested.

On the other hand, archaeofaunal evidence shows significant changes in livestock management techniques after the eighth century. The most remarkable phenomenon was, without doubt, the decrease in size of the three main domesticates precisely after the eighth century in Álava but, more generally, in the whole Iberian Peninsula (Grau, 2015b). The size of cattle, sheep/goats and pigs only increased again during the Late Middle Ages, reaching the size of their Roman counterparts during post-medieval times. There are different reasons for these biometrical changes. Some scholars have pointed out that these reductions would be linked to a major change in animal husbandry techniques, such as not practicing selective breeding, or the need for smaller animals adapted to new agrarian productive strategies (Henning, 2014; Grau, 2015b). All in all, it seems quite clear that the early medieval reduction in size is a result of important changes in livestock management, possibly including free-range keeping and rejection of larger breeds for reproduction. Summing up, it can be suggested that a new extensive livestock strategy has been introduced, accordingly with other agrarian evidence.

\section{DISCUSSION}

Even in a territory that seems not very hierarchical, such as the early medieval Basque Country, with no urban centres, castles or links to long-distance trading routes, we can suggest that a mix of intensive and non-specialized agriculture existed, with crop rotation and production diversification as risk-control mechanisms. Community-based farming management is detected from at least the ninth century, but it is quite likely that it was used one century before. In the end, early medieval agriculture was not a poor version of Roman agriculture or just the previous step to the early medieval one; it should be seen as

11. In contexts dated to the sixth to seventh centuries in Dulantzi and Aistra, cattle are the less frequent domestic taxon (between the 12 and the 35\%); during the eighth to tenth centuries, cattle are the most common taxon in Zornoztegi and Aistra (65-35\%); see GRAU (2015a). 
a far-reaching reorganization and innovative application of earlier technologies in such a way that there was neither a technological relapse nor a technological revolution in post-Roman times or in the Early Middle Ages (Henning, 2009: 164), but a re-adjustment of the socio-economic scale and an adaptation to a new socio-political context.

As historians have been claiming for decades, farming practices had a central role in articulating social and political practices that are key to analysing the historical dimension of peasantry during the Early Middle Ages. And, although it seems clear that the political horizons of local communities in Álava before the tenth century were limited, it does not mean that complex social dynamics were not taking place at a local or supra-local scale. In diachronic terms, the following main trends can be identified:

a) The apparent collapse of the central places of the Late Roman period led to a reorganisation of hierarchies at a local level and the transformation of agrarian practices. The foundation of new estate centers, such as Aistra, and focus of authority based on churches and other sites, reflect changeable social landscapes. As a result, new frameworks for micropolitics have been created in different directions. Although disperse settlement patterns are predominant, collective social practices have been created mainly in communal cemeteries or in the management of common resources, such us the exploitation of pastures and forests.

The scarce knowledge we have about the organization of Late Roman farming systems makes it difficult to evaluate the impact of this process on the social articulation of Basque landscapes. While there are no clear changes in animal husbandry, the emergence of the first silos and the progressive occupation of mountain spaces are two elements that characterize peasant agency in the modification of agrarian landscapes. In any case, these non-co-resident communities have less coherence than those from the centre of the Iberian Peninsula or the Duero Basin ${ }^{12}$. In the light of archaeological evidence, it is very difficult to define how the new island of authority ${ }^{13}$ worked in the local scale.

b) Political disarticulation may have favoured, from the late seventh century, the emergence of initiatives for power localization visible in the funerary and domestic records. These initiatives may constitute the necessary precedent for the

12. About the articulation of rural communities in inner Iberia during this same period, see VIGILEsCALERA (2007), Quirós (2013), and TEJERIZO (2017).

13. The term was coined by MARTín (2012). 
creation of a new socio-political scene that allowed the process of nucleation which occurred from the seventh and the eighth century. The agency for settlement nucleation and the formation of larger communities could have been the product of local communities as much as elite initiative in a competitive and negotiate context (Loveluck, 2013: 75; Quirós, 2020a). But, is nucleation a sign of "political maturity"? The idea that dispersion is equal to instability and that nucleation implies stability could be a false problem. Indeed, the interpretation of settlement patterns and peasant agency in the Early Medieval period might be determined by our notion of the high or late medieval village.

Besides, the creation of this village network is closely related to significant changes in farming practices. The decrease in size of domestic livestock, changes in human and livestock feeding that is attested by the isotopic analyses or extensive agrarian practices are some of the most remarkable trends. Moreover, the greater coherence of local communities may have favoured the development of coordinated and collective or semi-collective management practices (Oosthuizen, 2013; Quirós, 2020b). Does nucleation cause an increase in agricultural production, as scholars such as P. Crabtree have suggested? (Crabtree, 2010). Specialists in anthropological and political economy have questioned simple correlations (Price \& Feinman, 1995, 2012; Thurson \& Fisher, 2007). Certainly, we cannot talk in Álava about an "agricultural revolution", as recent projects have shown in other European contexts (Hamerow et al., 2019). At least during these centuries extensification was predominant to intensification, diversification of agrarian practices to specialization and the scale of aristocrat initiatives seems to be modest.

Sub-regional production networks are documented through pottery or flint evidence. For the last decades of the eighth century, high quality red painted pottery is found in some sites and the Urbasa and Treviño flint has been found in most of the Álava Plain sites. However, the economic and political horizons of the local societies in the seventh and eighth centuries are still limited to very restricted territories in the light of archaeological evidence.

c) On the other hand, these are not egalitarian societies. Without any castles or big centralized places of power, some "islands of authority" have been created, lasting sometime a number of centuries. In other words, the leopard spot model proposed by Chris Wickham (2005) can be useful to describe political economy in this period, taking into account the co-existence of difference micro-political systems. Looking within the local societies, we notice that there are subs- 
tantial differences between and inside the different local communities, although they are displayed in a different manner as compared to the previous period. Looking at the burial and domestic records, and in particular storage and consumption patterns, it can be inferred that these villages were formed by smallholders, dependent peasants, servants and other groups.

From this period some families and individuals can act on behalf of the entire communities. New middling social actors and enriched peasants became important, acting as elites inside the villages and having political aspirations in a framework of social mobility (Davies, 2007: 202-13; Quirós, 2019). The process for reorganizing field systems within the villages, a phenomenon that is more marked after the tenth century, could have been led by these new historical subjects.

Moreover, the written evidence shows the interaction of local aristocracies with peasant communities through the foundation of churches and monasteries inside villages, allowing the appropriation and use of communal lands and rights. Indeed, such aristocracies are focused on animal husbandry, because they own large livestock herds that need seasonal grazing in the mountains. For instance, the founder of San Román de Tobillas in $\mathrm{AD} 822$ gave to the new church a hundred cows, eighty mares, twenty horses, sheep and a couple of oxen (Larrea, 2007). Is there any connection between the reduction of the peasant animal sizes and the conflicts for the use of highland pasture and forest areas? Perhaps it was one of the components of a more generalized process based on extensive breeding practices, which affected livestock of both aristocrats and local communities.

d) Throughout the tenth to the twelfth centuries, we detect the greatest pressure on the territory of Álava in the post-Roman world. We observe a real agrarian growth in terms of intensification, visible on the changes in the use of woodland and communal areas, the construction of new agricultural fields, and the establishment of an efficient rent-collecting system that was used as a way to speculate with the necessities of communities in case of bad harvest or other difficulties. Further, from this period onwards, we can observe slight changes towards productive specialization, driven by seigniorial elites and growing proto-urban markets. In the eighth and ninth centuries local power was based 
on accumulating wealth and ostentation ${ }^{14}$, but from the tenth century wealth was used all over as a social instrument for domination and political institutionalisation in the context of networks linked with emerging central powers. Some local elite had access to those networks, while others were excluded.

In any case, sub-regional and local differences seem to be remarkable. In areas such as the Rioja Alavesa or the south of Álava, there are entire villages in the hands of a single owner or lord, as in the case of Torrentejo. There is also space for political experimentation, such as the case of the phenomenon of incastellamento. On the other hand, at the Álava Plain, the situation is much more articulated. First, the consolidation of complex socio-political centres took place, as in the case of Gasteiz, where ways of centralized control and organization of artisanal systems are visible. Also, the occurrence of milites inside small rural communities after the year 1000, as they appear in the written documents, is further evidence to support a new social and political scenario. In this territory, villages controlled by a single owner are very rare, and in a number of sites the process of seigniorialisation was only established predominantly after the thirteenth century, as we have observed in places like Zaballa.

\section{CONCLUSION}

At the end of this survey it can be concluded that intensive analysis of micro-territories through long-term projects is the most fruitful strategy to build an agricultural history and propose social interpretations. And although in recent years relevant steps have been taken towards the study of early-medieval agricultural landscapes in some areas (e.g. Gibert, 2018; Olmo, Castro \& Diarte, 2019), there is still a long way to go to make comparisons of a certain level. Undoubtedly the prominence of the potentes and peasant groups in several regions of northwestern Iberia can be explored through the textual sources of the tenth-eleventh centuries (e.g. Portass, 2017). But in the absence of archaeological records it is much more difficult to consider the entire early medieval period.

The Early Middle Age has been a period of profound changes in agricultural practices that have significantly transformed rural landscapes. The degree of specialization that had been identified in the Roman period gives way to more stable, secure and flexible agriculture, aimed to minimising risks. The innovations observed in Álava have affected crops,

14. As it is the case of architecture, personal ornaments or the consumption patterns observed in Aistra between the eighth and ninth centuries (see QUIRós, 2017). 
animals, field systems, implement, storage as well as management practices. How should we interpret in social terms the emergence of this new economic system?

Our knowledge of agrarian practices during the fifth-seventh centuries is still limited, but settlement patterns and palaeoenvironamental records show relevant changes in the rural landscapes. A more intense use of the mountain's areas surrounding the Álava Plain can be related to the development of vertical transhumance and a more extensive agriculture pattern. Even if nucleated sites are not attested, collective graveyards and common resources are key to the creation of non-co-resident communities.

\section{FIGURE 7}

\section{Some of the "island of authority" attested in early medieval Álava}

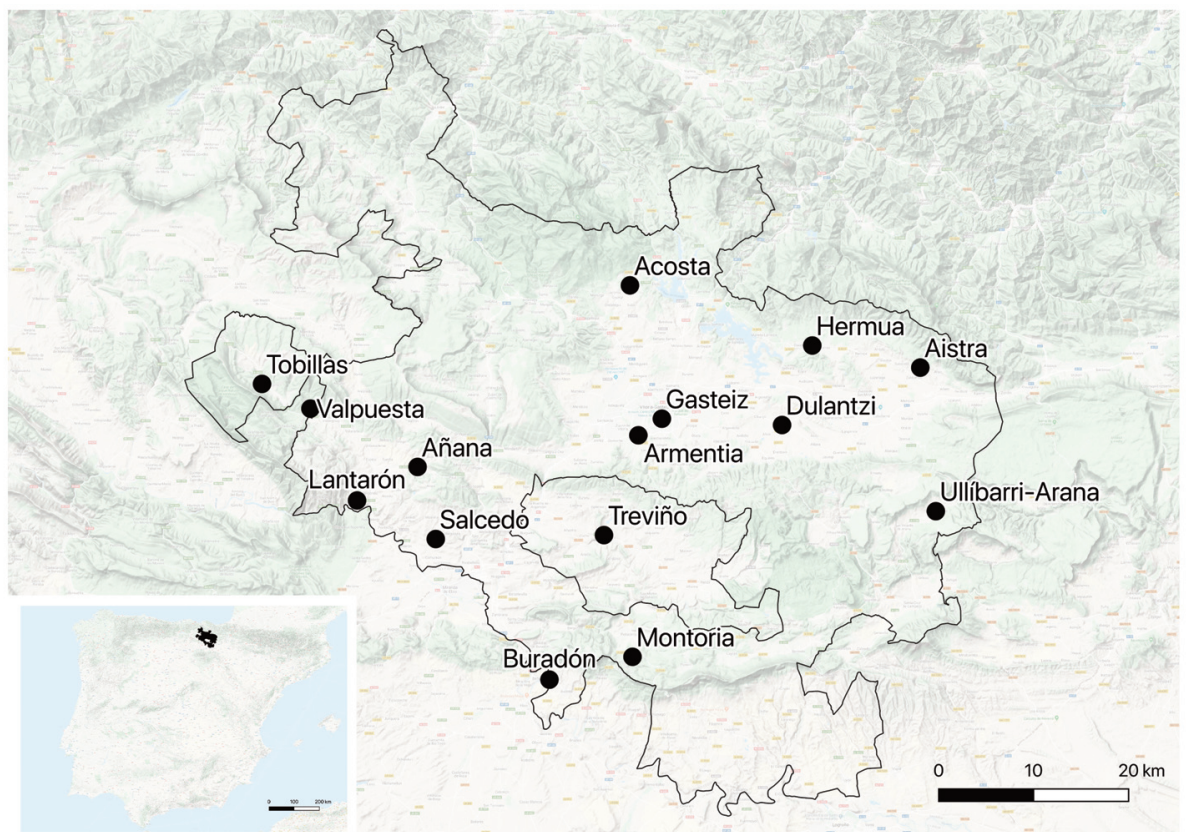

Source: Juan Antonio Quirós.

Nucleation is attested from the late seventh century on. Unlike the intensification and agricultural growth models that are associated with the village formation process and external inputs in various European contexts (Crabtree, 2010; McKerracher, 2018), the Álava case shows that different forms of social grouping have coexisted, which are not always based on co-resident bases. Besides, extensive agricultural practices rather than intensive are attested, even if some sites show different trends. As a result, it can be suggested that a certain grade of social tension and competition for the use of agrarian landscapes 
characterized the seventh-tenth centuries in the emergence of a number of local elites and social mobility. But only in the eleventh-twelfth centuries intensification practices are clearly documented.

The rural history of Álava in the Middle Ages shows that it is a fluid territory open to forms of social and political experimentation that cannot be explained by referring only to exogenous agents, "historical context" or tautological models increasingly complex towards the crystallization of feudalism. In contrast with inner Iberia, Catalonia or Galicia trends, the economic and political horizons of the local authorities developing throughout the Early Middle Ages are smaller. But of course, this does not determine that we are in the presence of egalitarian societies or that the sole peasantry agency has shaped productive strategies and agricultural landscapes. Binary models that oppose elite landscapes vs peasantry agency are too simple to explain the articulation of local societies that are progressively defining around or in the limits of the "islands of authority" distributed in the Álava territory (Fig. 7), and in general, throughout the area of old Castile. On the other hand, Álava shows a pattern characterized by the presence of distant aristocracies, hardly involved in agricultural production processes, intermediate elites showing differentiated consumption patterns resulting from regular income extraction, and heterogeneous peasant communities where there is room for social mobility and moral economy practices. This is a polycentric and competitive political system, and the notion of relational agency is key to understand these territories (Barrett, 2012).

In short, we should overcome models that prioritize peasant communities, aristocracies and external factors, or that underline the long continuity of economic and socio-political systems for the benefit of the analysis of local societies or small worlds (Davies, 1988), considered as spaces of complex interaction between a variety of agents.

\section{ACKNOWLEDGEMENTS}

This research was supported by the project "Peasant agency and social complexity in north-western Iberia in the medieval period" (Spanish Ministry of Economy, Industry and Competitiveness AEI/FEDER UE HAR2016-76094-C4-2R), the Research Group on Medieval Archaeology, Heritage and Cultural Landscapes (Government of the Basque Country, IT1193-19) and the Group of Rural Studies (Associated Unit UPV/EHUCSIC). I would like to express my gratitude to Margarita Fernández Mier, Alfonso Vigil-Escalera, Idoia Grau, Julio Escalona, Iñaki Martín Viso, Carlos Tejerizo, and two anonymous reviewers of Historia Agraria for all their comments, contributing to the improvement of an earlier version of the manuscript. 


\section{REFERENCES}

Agirre, J., Moraza, A., Mujika, J. A., Reparaz, X. \& Telleria, E. (2008). Primeros vestigios de un modelo económico de ganadería estacional especializada: Los fondos de cabaña tumulares de Arrubi y Esnaurreta (Aralar). Kobie, (XXVII), 105-31.

Alfaro E., Loza, M., Niso, J. \& Solaun, J. L. (2017). Iglesias, rentas y sistemas de almacenamiento en el País Vasco durante los siglos x y XI d. C.: El testimonio arqueológico de San Martín de Dulantzi (Alegría-Dulantzi, Álava). Archivo Español de Arqueología, (90), 247-70.

Alfonso de SALDAÑa, M. I. (1974). Las sernas en León y Castilla: Contribución al estudio de las relaciones socioeconómicas en el marco del señorío medieval. Moneda y Crédito, (129), 153-210.

Alonso, P. (2018). The Heritage Machine: Fetishism and Domination in Maragatería, Spain. London: Pluto Press.

ARIÑo, E. (2013). El hábitat rural en la Península Ibérica entre finales del siglo IV y principios del viII: Un ensayo interpretativo. Antiquité tardive, (21), 91-123.

Astill, G. (2010). The Long and the Short: Rural Settlement in Medieval England. In R. Goddard, J. LANGdon \& M. Müller (Eds.), Survival and Discord in Medieval Society: Essays in Honour of Christopher Dyer (pp. 11-28). Turhnout: Brepols.

Azkarate, A. \& García CAMINO, I. (2012). El espacio circumpirenaico occidental durante los siglos VI al X d. C. según el registro arqueológico: Algunos interrogantes. In L. Caballero, P. Mateos \& C. García De Castro (Eds.), Asturias entre visigodos y mozárabes. 6:Visigodos y omeyas (pp. 331-52). Madrid: Consejo Superior de Investigaciones Científicas.

Azkarate, A. \& Solaun, J. L. (2008). Excavaciones arqueológicas en el exterior de los conjuntos rupestres de Las Gobas (Laño, Burgos). Archivo Español de Arqueología, (81), 133-49.

Azkarate, A. \& Solaun, J. L. (Eds.) (2013). Arqueología e historia de una ciudad: Los orígenes deVitoria-Gasteiz. Bilbao: Universidad del País Vasco.

Azkarate, A., Martínez Torrecilla, J. M. \& Solaun, J. L. (2011). Metalurgia y hábitat en el País Vasco de época medieval: El asentamiento ferrón de Bagoeta, Álava (ss. VII-XIV d. C.). Arqueología y Territorio Medieval, (18), 71-89.

Ballesteros, P., Criado, F. \& ANdrade, J. M. (2006). Formas y fechas de un paisaje agrario de época medieval: "A Cidade da Cultura" en Santiago de Compostela. $A r$ queología Espacial, (26), 195-225.

BARbero, A. \& Vigil, M. (1974). Sobre los orígenes sociales de la Reconquista. Barcelona: Ariel. 
BARCELÓ, M. (1995). Crear, disciplinar y dirigir el desorden: La renta feudal y el control del proceso de trabajo campesino: Una propuesta sobre su articulación. Taller d'Història, (6), 61-72.

BARRETt, J. C. (2012). Agency: A Revisionist Account. In I. Hodder (Ed.), Archaeological Theory Today (pp. 146-66). Cambridge: Polity Press.

Barroso, R., Carrobles, J., Morín, J. \& SÁnchez Ramos, I. M. (2015). Los Hitos: Arisgotas (Orgaz, Toledo): De palacio a panteón visigodo. Madrid: Audema.

Bermejo, J. (2017). Roman Peasant Habitats and Settlement in Central Spain (1 ${ }^{\text {st }}$ c. B. C. $-4^{\text {th }}$ c. A. D.). Fournal of Roman Archaeology, (30), 351-71.

Chavarria, A., Lewit, T. \& IzDebski, A. (2019). Settlement and Society in the Late Antique Mediterranean, $4^{\text {th }}-7^{\text {th }}$ c.: An Overview. In A. IzDEBSKI \& M. MulRYAN (Eds.), Environment and Society in the Long Late Antiquity (pp. 319-29). Leiden: Brill.

Chavarria, A. (2013). ¿Castillos en el aire?: Paradigmas interpretativos "de moda" en la arqueología medieval española. En Actas XXXIX Semana de Estudios Medievales: De Mahoma a Carlomagno: Los primeros tiempos (siglos VII-IX) (pp. 131-66). Pamplona: Gobierno de Navarra.

Corella, J. P., Stefanova, I., El Anjoumi, A., Rico, E., Giralt, S., Moreno, A., Plata, A. \& VAlero, B. L. (2013). A 2500-Year Multi-Proxy Reconstruction of Climate Change and Human Activities in Northern Spain: The Lake Arreo Record. Paleogeography, Paleoclimatology, Paleoecology, (386), 555-68.

Crabtree, P. J. (2010). Agricultural Innovation and Socio-Economic Change in Early Medieval Europe: Evidence from Britain and France. World Archaeology, 42 (1), 12236.

DAvies, W. (2007). Acts of Giving: Individual, Community, and Church in Tenth-Century Christian Spain. Oxford: Oxford University Press.

DAvIES, W. (1988). SmallWorlds:TheVillage Community in Early Medieval Brittany. London: Duckworth.

Diarte, P. (2018). Late Antique and Early Medieval Hispania: Landscapes without Strategy? Oxford: Oxbow.

Díaz de Durana, J. R. (1986). Álava en la Baja Edad Media: Crisis, recuperación y transformaciones socioeconómicas (c. 1250-1525). Vitoria-Gasteiz: Diputación Foral de Álava.

Durand, A. \& Leveau, P. (2004). Farming in Mediterranean France and Rural Settlement in the Late Roman and Early Medieval Periods: The Contribution from Archaeology and Environmental Sciences in the Last Twenty Years. In M. BARCELÓ \& F. Sigaut (Eds.), The Making of Feudal Agricultures? (pp. 177-253). Leiden/Boston: Brill.

Escalona, J. (2009). The Early Castilian Peasantry: An Archaeological Turn? Fournal of Medieval Iberian Studies, 1 (2), 119-45. 
EsCALONA, J. \& MARTIN, I. (2013). Los palatia, puntos de centralización de rentas en la meseta del Duero (siglos IX-XI). In A. VigIL-Escalera, G. BIANCHI \& J. A. QUiRós (Eds.), Horrea, Barns and Silos: Storage and Incomes in Early Medieval Europe (pp. 103-26). Bilbao: Universidad del País Vasco.

EspinosA, U. (2011). La villa prolongada en el tiempo: El caso de Parpalinas (Pipaona de Ocón, La Rioja). In J. A. Quirós (Ed.), Vasconia en la Alta Edad Media, 450-1000: Poderes y comunidades rurales en el norte peninsular (pp. 181-92). Bilbao: Universidad del País Vasco.

Fernández, D. (2017). Aristocrats and Statehood in Western Iberia, 300-600 C. E. Philadelphia: University of Pennsylvania Press.

FERNÁNDEZ Mier, M. (2018). De la Arqueología del paisaje a la Arqueología Agraria. In J. A. Quirós (Ed.), Treinta años de Arqueología Medieval en España (pp. 225-70). Oxford: Archaeopress.

FERnÁNDEZ Mier, M. \& Quirós, J. A. (2015). El aprovechamiento de los espacios comunales en el noroeste de la Península ibérica entre el período romano y el medieval. Il Capitale Culturale: Studies on the Value of Cultural Heritage, (12), 689-717.

Fernández Mier, M., Fernández Fernández, J., Alonso, P., López Sáez, J. A., PéREZ Díaz, S. \& Hernández Beloqui, B. (2014). The Investigation of Currently Inhabited Villages of Medieval Origin: Agrarian Archaeology in Asturias (Spain). Quaternary International, (346), 41-55.

Flannery, K. V. \& Marcus, J. (2012). The Creation of Inequality: How Our Prehistoric Ancestors Set the Stage for Monarchy, Slavery, and Empire. Cambridge: Harvard University Press.

Franco, F. J., EtXeZARRAGa, I. \& Alberdi, X. (2015). Los orígenes de la tecnología del hierro en el País Vasco: Ferrerías de Monte o Haizeolak. Kobie Serie Paleoantropología, (34), 267-82.

Galop, D., Ruis, D., Cugny, C. \& MaZier, F. (2013). A History of Long-Term HumanEnvironment Interactions in the French Pyrenees Inferred from the Pollen Data. In L. R. LozNy (Ed.), Continuity and Change in Cultural Adaptation to Mountain Environments (pp. 19-30). New York: Springer. (Studies in Human Ecology and Adaptation, 7).

GARCÍA DE CoRTÁzAR, J. A. (1988). La sociedad rural en la España medieval. Madrid: Siglo XXI.

Gibert, J. (2018). La fi del món antic $i$ els inicis de l'Edat Mitjana a la Catalunya Central: Economia, Societat $i$ Territori entre els segles V $i$ VIII. Tarragona: Institut Catala d'Arqueologia Classica.

GIL, L. (2004). Los silos de La Llana (Labastida, Álava): Memoria de las campañas de excavación de 1995, 1996 y 1997. Estudios de Arqueología Alavesa, (21), 281-310. 
GiL, E. \& Filloy, I. (2000). Museo de Arqueología de Álava: La Romanización. VitoriaGasteiz: Diputación Foral de Álava.

Grant, A. (2002). Food, Status and Social Hierarchy. In P. Miracle \& N. MiLner (Eds.), Consuming Passions and Patterns of Consumption (pp. 17-23). Cambridge: Cambridge University Press.

GraU, I. (2015a). The Zooarchaeology of Medieval Alava in its Iberian Context. Oxford: British Archaeological Reports.

GRAU, I. (2015b). Livestock Management in Spain from Roman to Post-Medieval Times: A Biometrical Analysis of Cattle, Sheep/Goat and Pig. Fournal of Archaeological Science, (54), 123-34.

GRAU, I. (2017). Socio-Economic Status and Religious Identity in Medieval Iberia:The Zooarchaeological Evidence. Environmental Archaeology, 22 (2), 189-99.

HALstead P. \& O'SHEA, J. (1989). BadYear Economic: Cultural Responses to Risk and Uncertainty. Cambridge: Cambridge University Press.

Hamerow, H. (2002). Early Medieval Settlements: The Archaeology of Rural Communities in North-West Europe 400-900. Oxford: Oxford University Press.

Hamerow, H. (2012). Rural Settlements and Society in Anglo-Saxon England. Oxford: Oxford University Press.

Hamerow, H., Boogaard, A., Charles, M., Ramsey, C., Thomas, R., Forster, E., Holmes, M., MCKerracher, M., NeIL, S. \& STroud, E. (2019). Feeding Anglo-Saxon England:The Bioarchaeology of an Agricultural Revolution. Antiquity, 93 (368), e12.

Hassan, F. A. (2009). Human Agency, Climate Change, and Culture: An Archaeological Perspective. In S. A. Crate \& M. Nuttall (Eds.), Anthropology and Climate Change From Encounters to Actions (pp. 39-69). London: Routledge.

HeNNING, J. (2009). Revolution or Relapse?: Technology, Agriculture and Early Medieval Archaeology in Germanic Central Europe. In G. Ausenda, P. Delogu \& C. WiCKHAM (Eds.), The Langobards before the Frankish Conquest: An Ethnographic Perspective (pp. 149-73). Woodbridge: Boydell Press.

Henning, J. (2014). Did the "Agricultural Revolution" go East with Carolingian Conquest? In G. AusENDA, J. Hines \& H. STEUER (Eds.), The Baiuvarii and Thuringi: An Ethnographic Perspective (pp. 331-60). Woodbridge: Boydell Press.

HERNÁNDEZ BELOQUI, B. (2015). Los paisajes medievales del norte peninsular: Registros paleopalinológicos de la Llanada Alavesa y la Cuenca de Treviño. Unpublished $\mathrm{PhD}$ thesis. Bilbao: Universidad del País Vasco.

Hilton, R. H. (1985). Class Conflict and the Crisis of Feudalism: Essays in Medieval Social History. London: Hambledon Press.

IzDEBski, A. \& Mulryan, M. (Eds.) (2019). Environment and Society in the Long Late Antiquity. Leiden: Brill. 
Johnson, A. W. \& Earle, T. (2000). The Evolution of Human Societies: From Foraging Group to Agrarian State. Stanford: Stanford University Press.

LARREA, J. J. (2007). Construir iglesias, construir territorio: Las dos fases altomedievales de San Román de Tobillas (Álava). In J. López Quiroga, A. M. Martínez Tejera \& J. MoRín (Coords.), Monasteria et territoria: Elites, edilicia y territorio en el mediterráneo medieval (siglos V-XI) (pp. 321-36). Oxford: British Archaeological Reports.

Llanos, A. \& Urteaga, M. M. (2002). Notas sobre el pastoreo durante la Prehistoria en el País Vasco peninsular. Estudios de Arqueología Alavesa, (19), 82-95.

López Sáez, J. A., Pérez Díaz, S., Galop, D., Alba, F. \& Abel, D. (2019). A Late Antique Vegetation History of the Western Mediterranean in Context. In A. IZDEBSKI \& M. MulRYAN (Eds.), Environment and Society in the Long Late Antiquity (pp. 83-104). Leiden: Brill.

Loveluck, C. (2013). Northwest Europe in the Early Middle Ages, c. AD 600-1150: A Comparative Archaeology. Cambridge: Cambridge University Press.

Lubritto, C., García Collado, M. I., Ricci, P., Altieri, S., Sirignano, C. \& Quirós, J. A. (2017). New Dietary Evidence on the Medieval Rural Communities of the Basque Country (Spain) from Carbon and Nitrogen Stable Isotope Analysis: Social Insights, Diachronic Changes and Geographic Comparison. International fournal of Osteoarchaeology, 27 (6), 984-1002.

Manzanilla, L. R. \& Rothman, M. S. (2016). Storage in Ancient Complex Societies: Administration, Organization, and Control. London: Routledge.

Marcus, J. \& Stanish, C. (Eds.) (2006). Agricultural Strategies. Los Angeles: Cotsen Institute of Archaeology, University of California.

MARTín, I. (2012). Un mundo en transformación: Los espacios rurales en la Hispania post-romana (siglos V-VII). In L. CABAllero, P. MATeOs \& T. Cordero (Eds.), Visigodos y omeyas: El territorio (pp. 31-63). Madrid: Consejo Superior de Investigaciones Científicas.

Martínez Jiménez, J., Sastre, I. \& Tejerizo, C. (2018). The Iberian Peninsula between 300 and 850: An Archaeological Perspective. Amsterdam: Amsterdam University Press.

McCormick, F., Kerr, T. R., McClatchie, M. \& O'Sullivan, A. (2014). Early Medieval Agriculture, Livestock and Cereal Production in Ireland AD 400-1100. Oxford: Archaeopress. (British Archaeological Reports International Series, 2647).

McKerracher, M. (2018). Farming Transformed in Anglo-Saxon England: Agriculture in the Long Eighth Century. Oxford: Windgather Press.

MoraZA, A. \& MUJIKA, J. A. (2005). Establecimientos de habitación al aire libre: Los fondos de cabaña de morfología tumular: Características, proceso de formación y cronología. Veleia, (22), 77-110. 
Morehat, C. T. \& De Lucia, K. (Eds.) (2015). Surplus: The Politics of Production and the Strategies of Everyday Life. Boulder: University of Colorado Press.

Mujika, J. A., Agirre, J., Edeso, J. M., Lopetegi, A., Pérez Díaz, S., Ruiz Alonso, M., TARRIÑO, A. \& YUSTA, I. (2013). La continuidad de la actividad pastoril durante la época romana en la zona de Argarbi (Sierra de Aralar, Gipuzkoa). Kobie. Serie Paleoantropologia, (32), 217-58.

Narbarte-Hernández, J., Iriarte, E., Rad, C., Tejerizo, C., Fernández Eraso, J. \& Quirós-CASTILlO, J. A. (2020). Long-term construction of vineyard landscapes in the Ebro Valley: The deserted village of Torrentejo (Basque Country, Spain). Catena, 187, 104417.

Olmo, L., Castro, M. \& Diarte, P. (2019). Transformación social y agrosistema en el interior peninsular durante la Alta Edad Media (s. VI-VIII D. C.): Nuevas evidencias desde Recópolis (Zorita de los Canes, Guadalajara). Lucentvm, (XxxvIII), 355-77.

Oosthuizen, S. (2013). Beyond Hierarchy:The Archaeology of Collective Governance. World Archaeology, 45 (5), 714-29.

Oroz, J. (1978). Sancti Braulionis Caesaraugustani Episcopi:Vita Sancti Aemiliani. Perficit, (9), 165-227.

Peña, L., Perez, G., Alonso, N., Antolín, F., Teira, A., Tereso, J., Montes, E. \& LóPEZ Reyes, D. (2019). Roman and Medieval Crops in the Iberian Peninsula: A First Overview of Seeds and Fruits from Archaeological Sites. Quaternary International, (499A), 49-66.

Pérez Díaz, S. \& López Sáez, J. A. (2014). Prados de Randulanda Peat Bog (Basque Country, Northern Iberian Peninsula, Spain). Grana, 53 (3), 252-54.

Pérez Díaz, S., Ruiz, M., López Sáez, J. A., Solaun, J. L., Azkarate, A. \& Zapata, L. (2015). A Palaeoenvironmental and Palaeconomic Approach to the Early Middle Age Record from the Village of Gasteiz (Basque Country, Northern Iberian Peninsula). Vegetation History and Archaeobotany, 24 (6), 683-97.

PorTass, R. (2017). The Village World of Early Medieval Northern Spain: Local Community and the Land Market. London: Royal Historical Society.

Price, T. D. \& Feinman, G. M. (1995). Foundations of Prehistoric Social Inequality. In T. D. Price \& G. M. FeInMan (Eds.), Foundations of Social Inequality (pp. 3-11). New York: Plenum Press.

Price, T. D. \& Feinman, G. M. (Eds.) (2012). Pathways to Power: New Perspectives on the Emergence of Social Inequality. New York: Springer.

Quirós, J. A. (2012a). Sobrón (San Martín y La Viña). Arkeoikuska, (12), 94-9.

Quirós, J. A. (Ed.) (2012b). Arqueología del campesinado medieval: La aldea de Zaballa. Bilbao: Universidad del País Vasco.

Quirós, J. A. (Ed.) (2013b). El poblamiento rural de época visigoda en Hispania: Arqueología del campesinado en el interior peninsular. Bilbao: Universidad del País Vasco. 
QUIRós, J. A. (2014). Oltre la frammentazione postprocesualista: Archeologia agraria nel NO della Spagna. Archeologia Medievale, (XLI), 23-37.

Quirós, J. A. (2016). Social Complexity in Early Medieval Rural Communities:The North-

Western Iberia Archaeological Record. Oxford: Archaeopress.

Quirós, J. A. (2017). Longhouses, biografía de la casa y complejidad social en el noroeste peninsular en la alta edad media. Arqueología de la Arquitectura, (14).

Quirós, J. A. (2019). Arqueología de una comunidad campesina medieval: Zornoztegi (Álava). Bilbao: Universidad del País Vasco.

Quirós, J. A. (2020a).Village Formation, Social Memories and the Archaeology of Rural Communities in North-Western Iberia. In J. A. QuIRós (Ed.), Archaeology of Social Inequality in Early Medieval Europe: Local Societies and Beyond. Turhnout: Brepols.

Quirós, J. A. (2020b). An Archaeology of the "Small Worlds": Social Inequality in Early Medieval Iberian Rural Communities. Fournal of Iberian Medieval Studies, 12 (1), 327.

Quirós, J. A. \& Nicosia, C. (2019). Reconstructing Past Terraced Agrarian Landscapes in the Ebro Valley: The Deserted Village of Torrentejo, Basque Country, Spain. Geoarchaeology, 34 (6), 684-97.

Quirós, J. A. \& VigiL-EsCALERA, A. (2006). Networks of Peasant Villages between Toledo and Velegia Alabense, Northwestern Spain (V-Xth Centuries). Archeologia Medievale, (33), 79-130.

RipPon, S. (2010). Landscape Change during the "Long Eighth Century" in Southern England. In N. J. Higham \& M. J. Ryan (Eds.), The Landscape Archaeology of Anglo-Saxon England (pp. 39-64). Woodbridge: Boydell Press.

Rivera, A. (Ed.) (2003). Historia de Álava. San Sebastián: Nerea.

SÁENZ DE URTURI, F. (2011). Memoria de las intervenciones arqueológicas realizadas en Astúlez: Sondeos estratigráficos en los yacimientos de El Castillo y Santa Coloma (Astúlez, Valdegobía, Álava). Estudios de Arqueología Alavesa, (27), 229-358.

SÁnchez Albornoz, C. (1966). Despoblación y repoblación del Valle del Duero. Buenos Aires: Instituto de Historia de España.

SÁnCHEZ Rincón, R. (2011). La evolución del hábitat en el yacimiento de San Andrés (Salinas de Añana, Álava): Primera aproximación. Estudios de Arqueología Alavesa, (27), 217-28.

Sirignano, C., Grau, I., Ricci, P., García Collado, M. I., Altieri, M., Quirós, J. A. \& Lubritto, C. (2014). Animal Husbandry during Early and High Middle Ages in the Basque Country (Spain). Quaternary International, (346), 138-48.

Solaun, J. L. (2005). La cerámica medieval en el País Vasco (siglos VIII-XIII): Sistematización, evolución y distribución de la producción. Vitoria-Gasteiz: Universidad del País Vasco/Gobierno Vasco. 
SOPELANA, I. (2012). Estudios arqueobotánicos del yacimiento de Zaballa (Iruña de Oca, Álava). In J. A. Quirós (Dir.), Arqueología del campesinado medieval: La aldea de Zaballa (pp. 452-79). Bilbao: Universidad del País Vasco.

Stagno, A. M. \& Tejerizo, C. (2016). Montes de utilidad pública de Álava y Gipuzkoa. Arkeoikuska, (2016), 428-37.

Stevens, C. J. \& Fuller, D. Q. (2012). Did Neolithic Farming fail?: The Case for a Bronze Age Agricultural Revolution in the British Isles. Antiquity, 86 (333), 707-22.

Tejado, J. M. (2012). Castros altomedievales en el alto Iregua (La Rioja): El Castillo de los Monjes. In J. A. Quirós \& J. M. TejADo (Eds.), Los castillos altomedievales en el noroeste de la Península Ibérica (pp. 163-92). Bilbao: Universidad del País Vasco.

Tejerizo, C. (2017). Arqueología de las sociedades campesinas en la cuenca del Duero durante la Primera Alta Edad Media. Bilbao: Universidad del País Vasco.

Thurson, T. L. \& Fisher, C. T. (2007). Seeking a Richer Harvest:The Archaeology of Subsistence Intensification, Innovation and Change. New York: Springer.

VArón, F. R. (2013). Iglesia de San Martín de Tours, en Gazeo. Arkeoikuska, (13), 76-8.

VigIL-EsCALERA, A. (2000). Cabañas de época visigoda: Evidencias arqueológicas del sur de Madrid: Tipología, elementos de datación y discusión. Archivo Español de Arqueología, 73 (181-182), 223-252.

VIGIL-EsCALERA, A. (2007). Granjas y aldeas altomedievales al norte de Toledo (450-800 d. C.). Archivo Español de Arqueología, (80), 239-84.

Vigil-EsCAleRA, A. (2015). Los primeros paisajes altomedievales en el interior de Hispania: Registros campesinos del siglo quinto d. C. Bilbao: Universidad del País Vasco.

Wickнам, C. (2005). Framing the Early Middle Ages: Europe and the Mediterranean, 400-800. Oxford: Oxford University Press.

WickHAm, C. (2011). Conclusiones. In J. A. Quirós (Ed.), Vasconia en la Alta Edad Media, 450-1000: Poderes y comunidades rurales en el Norte Peninsular (pp. 87-90). Bilbao: Universidad del País Vasco. 